\title{
SUKUK AND BONDS IN INDONESIA: AN OVERVIEW
}

\author{
Doli Witro, Iwan Setiawan \\ UIN Sunan Gunung Djati Bandung \\ doliwitro01@gmail.com, iwansetiawan@uinsgd.ac.id
}

\begin{abstract}
From the early 1920 s to the late 20th century, there were at least 25 financial crises globally. In 2018, the Global Islamic Finance Report reported that Indonesia has tremendous potential to develop Islamic finance. Some of the Islamic financial products that can be developed in Indonesia are bonds and sukuk. Bonds are a product of the capital market. In its development, bonds have undergone relatively rapid innovation, which provides room for issuing Islamic bonds known as sukuk. This paper discusses the difference between sukuk and bonds. This paper aims to look at the differences between sukuk and bonds and the opportunities for issuance, application, and development of sukuk in Indonesia. This research is qualitative research that is literature. As for obtaining comprehensive results, this study uses two approaches consisting of a socio-historical approach and content analysis. The analysis results show that sukuk are in principle the same as bonds, with the main differences, among others, in the use of the concept of return and profit-sharing as a substitute for interest.
\end{abstract}

Keywords: Sukuk; Bond; Sharia Bonds; Capital market; Indonesia 


\begin{abstract}
ABSTRAK
Pada awal tahun 1920 sampai akhir abad 20-an setidaknya telah terjadi 25 kali krisis keuangan di dunia. Pada tahun 2018, Global Islamic Finance Report melaporkan bahwa Indonesia memiliki potensi luar biasa untuk mengembangkan keuangan syariah. Beberapa di antara produk ekonomi syariah yang dapat dikembangkan di Indonesia adalah obligasi dan sukuk. Pada dasarnya, obligasi merupakan salah satu produk dari pasar modal. Dalam perkembangannya, obligasi telah mengalami inovasi cukup pesat, yang memberikan ruang untuk diterbitkannya obligasi syariah yang dikenal dengan istilah sukuk. Tulisan ini membahas tentang perbedaan sukuk dan obligasi. Tulisan ini bertujuan melihat perbedaan sukuk dan obligasi serta peluang penerbitan, penerapan, dan perkembangan sukuk di Indonesia. Penelitian ini merupakan penelitian kualitatif yang bersifat pustaka. Adapun untuk memperoleh hasil yang komprehensif, penelitian ini menggunakan dua pendekatan yang terdiri dari pendekatan sosio-historis dan analisis konten. Hasil analisis menunjukkan sukuk pada prinsipnya sama dengan obligasi, dengan perbedaan pokok antara lain berupa penggunaan konsep imbalan dan bagi hasil sebagai pengganti bunga.
\end{abstract}

Kata Kunci: Sukuk; Obligasi; Obligasi Syariah; Pasar Modal; Indonesia 


\section{INTRODUCTION}

From the early 1920s to the late 20th century, there were at least 25 financial crises globally. This event was caused by an event called bubble (bubble economics) in the world economic system. This economic bubble affects countries that do not yet have a solid financial basis. This can be seen in the accelerated rate of money circulation. In the 1990s, Indonesia experienced an economic crisis by the economic turmoil of Southeast Asia at that time. Due to large-scale lending or credit by banks to developers and consumers in America, this resulted in many undeformed loans, which eventually led to the 2008 crisis. It is suspected that the leading cause of this crisis was usury or interest-based transactions, which has been ingrained in the conventional economic system at that time. ${ }^{1}$

In 2018, the Global Islamic Finance Report reported that Indonesia has tremendous potential to develop Islamic

\footnotetext{
1 M Anwar Rifa'i and Rois Ibnu Sina, “Analisis Perkembangan Dan Resistansi Sukuk Korporasi Dalam Produk Pasar Modal," Jurnal Ekonomi Dan Perbankan Syari'ah 11, no. 1 (2019): 34, https://doi.org/10.24235/amwal.v11i1.4406.

2 SIti Latifah, "Peran Sukuk Surat Berharga Syariah Negara (SBSN) Dalam Pertumbuhan Pembangunan

finance. Indonesia is supported by the largest Muslim population in the world. In addition, it is also supported by a demographic bonus, a large middle class, the largest economy among Muslim countries, high economic growth, and relatively low penetration of Islamic finance. ${ }^{2}$

Some of the Islamic financial products that can be developed in Indonesia are bonds and sukuk. Bonds are one of the products of the capital market, which emphasizes how a person provides capital. In its development, bonds have undergone relatively rapid innovation. Likewise, Islamic or sharia economics, which is currently experiencing rapid development, also provides space for the issuance of Islamic bonds known as sukuk. ${ }^{3}$

Sukuk is one of the Islamic financial instruments that has been issued by both the state and corporations. Several countries have become regular issuers of sukuk, such as Malaysia, Bahrain, Brunei

Ekonomi Indonesia," Jurnal IImiah Ekonomi Islam 6, no. 3 (2020): 421, https://doi.org/10.29040/jiei.v6i3.1369.

${ }^{3}$ Rifa'i and Sina, "Analisis Perkembangan Dan Resistansi Sukuk Korporasi Dalam Produk Pasar Modal," 34-35. 
Darussalam, United Arab Emirates, Qatar, Pakistan, and Saxony Anhalt-Germany. ${ }^{4}$ Empirical facts prove that sukuk have been widely used by the Muslim community in the Middle Ages in securities that represent financing obligations derived from trade and other commercial

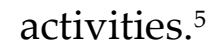

On the other hand, the impact of the issuance of Islamic bonds will increase the company's leverage. In addition, the company gets a reduction in the share of earnings paid for corporate taxes in the form of a tax shield. The use of debt can also reduce the value of shares due to the influence of interest costs and bankruptcy costs that may arise from debt. To meet the need for funds, one way that companies can do this is to issue bonds. The practice of Islamic bonds is different from conventionally managed bonds. The existence of the principle of prohibiting interest in Islam impacts limiting the use of the interest component in financial

\footnotetext{
4 Husnul Khatimah, "Sukuk Dan Kontribusinya Dalam Pembiayaan Pembangunan," Optimal: Jurnal Ekonomi Dan Kewirausahaan 11, no. 1 (2017): 87, https://doi.org/10.33558/optimal.v11i1.211.

5 Hulwati Hulwati, "Investasi Sukuk: Perspektif Ekonomi Syariah," JEBI (Jurnal Ekonomi Dan Bisnis
}

instruments. One application in bonds is the use of a discount rate in the calculation of bond interest. So that an alternative Islamic bond, known as sukuk, was issued. $^{6}$

Research on sukuk and bonds has been done. Some of them, Hanapi (2019) about the application of sukuk and sharia bonds in Indonesia; Trisilo (2014) about the application of contracts on sharia bonds and state sukuk (State Sharia Securities (Surat Berharga Syariah Negara/SBSN); Herli dan Nuraniyah (2018) about market reaction to the issuance of Islamic bonds (sukuk) in Indonesia; Hardianti and Widarjono (2017) about the impact of the issuance of conventional sukuk and bonds on company stock returns in Indonesia; Purnamawati (2015) about the comparison of sukuk and bonds (review from a financial and accounting perspective); Nasrifah (2019) about sukuk (sharia bonds) in the perspective of Islamic finance.
Islam) 2, no. 1 (2017): 89 , https://doi.org/10.15548/jebi.v2i1.70.

6 Nur Indah Hardianti and Agus Widarjono, "Dampak Penerbitan Sukuk Dan Obligasi Konvensional Terhadap Return Saham Perusahaan Di Indonesia," Jurnal Ekonomi \& Keuangan Islam 3, no. 1 (2017): 44, https://doi.org/10.20885/jeki.vol3.iss1/art6. 
This paper discusses the difference between sukuk and bonds. In addition, it also discusses the issuance, application, and development of sukuk in Indonesia. Thus, the development of sukuk in Indonesia needs to be studied more deeply in order to maximize the role of the Islamic financial system offered by Islamic economics to facilitate Muslims in particular and society in general in order to achieve the primary goal of Islamic economics, namely falah in the world and the hereafter. ${ }^{7}$ This paper aims to look at the differences between sukuk and bonds and the opportunities for the issuance, application, and development of sukuk in Indonesia.

\section{Method}

This research is qualitative research that is literature. As for obtaining comprehensive results, this study uses two approaches consisting of a socio-historical approach and content analysis. The sociohistorical approach highlights the

\footnotetext{
7 Rifa'i and Sina, "Analisis Perkembangan Dan Resistansi Sukuk Korporasi Dalam Produk Pasar Modal," 35.

8 Afifatul Munawiroh and Rumawi, "Melacak Investasi Syariah: Studi Perkembangan Sukuk Bagi Pasar

sociological and historical aspects. This approach consists of three aspects: first, the philosophical aspect, which is the answer to current law; second, the juridical aspect, which is a solid reason to address the issues of Muslims today; and third, the sociological aspect as a way of life for the people of Indonesia. Meanwhile, the content analysis approach refers to legislation and laws that are critically examined. In addition, it is also equipped with journals that discuss sukuk and bonds. $^{8}$

\section{RESULTS AND DISCUSSION}

\section{Definition of Sukuk}

Sukuk is a paper (book) or note on which there is an order from someone to pay a certain amount of money to another person whose name is written on the paper. The word sukuk comes from the Persian language, namely "jak", then entered into Arabic with "shak". Goitien mentions that "shak" is the origin of the

Modal Syariah Di Indonesia," Kertha Semaya 8, no. 10 (2020): 1554, https://doi.org/10.24843/KS.2020.v08.i10.p06. 
word "check or cheque", which is found in English, basically debt securities. ${ }^{9}$

According to the Accounting and Audition Organization for Islamic Finance Institution (AAOFI), a sukuk is a certificate of equal value representing a total share of tangible assets, benefits and services, ownership of assets in a project, or ownership in specific investment activity. ${ }^{10}$ According to the State Sharia Securities Law (SBSN), sukuk are securities issued based on sharia principles, as evidence of the share of participation in SBSN assets, both in rupiah and foreign currencies. ${ }^{11}$

According to Bapepam and Financial Institutions No. IX.A.13, concerning the issuance of sharia securities, defines sukuk as sharia securities in the form of

\footnotetext{
${ }^{9}$ Nafsiah, "Analisis Pengembangan Sukuk Negara Dan Mekanisme Transaksinya Pada Pasar Modal Di Indonesia," Al-Infaq, Ekonomi Islam 5, no. 1 (2014): 18, http://ejournal.uika-bogor.ac.id/index.php/alinfaq/article/view/40; Muhammad Iqbal Fasa, "Sukuk: Teori Dan Implementasi," Li Falah: Jurnal Studi Ekonomi Dan Bisnis Islam 1, no. 1 (2016): 81, https://doi.org/10.31332/lifalah.v1i1.476.

10 Endri, "Permasalahan Pengembangan Sukuk Korporasi Di Indonesia Menggunakan Metode Analytical Network Process (ANP)," Jurnal Keuangan Dan Perbankan 13, no. 3 (2009): 360, http://jurnal.unmer.ac.id/index.php/jkdp/article/view/ 1085; Ika Indriasari, "Sukuk Sebagai Alternatif Instrumen Investasi Dan Pendanaan," BISNIS : Jurnal Bisnis Dan Manajemen Islam 2, no. 1 (2014): 62, https://doi.org/10.21043/bisnis.v2i1.5250.
}

certificates or proof of ownership of the same value and representing an indefinite portion, certain tangible assets, the value of benefits, services, project assets or investment activities that have been determined. ${ }^{12}$ Meanwhile, according to the 2004 National Sharia Council (DSN), fatwa, sukuk, or sharia bonds are longterm securities based on sharia principles issued by issuers to sharia bondholders that require issuers to pay income to sharia bondholders in the form of profitsharing/margin/fees and payback bond funds at maturity. ${ }^{13}$

Based on the explanation above, in general, sukuk are assets that support stable income, can be traded and are certificates of trust that are following sharia. The primary condition why this

11 Rizky Suci Ramadayanti, Dedy Mainata, and Angrum Pratiwi, "Peran Sukuk Negara Dalam Pembiayaan Infrastruktur," Al-Tijary 2, no. 2 (January 2, 2017): 159, https://doi.org/10.21093/at.v2i2.788.

12 Nasrifah, "Sukuk (Obligasi Syariah) Dalam Perspektif Keuangan Islam," 69.

13 Endri, "Permasalahan Pengembangan Sukuk Korporasi Di Indonesia Menggunakan Metode Analytical Network Process (ANP)," 360-61; Atika Atika and Dwi Saraswati, "Analisis Pengaruh Penerbitan Dana Sukuk Terhadap Kinerja Perbankan Syariah," JURNAL AKUNTANSI DAN BISNIS: Jurnal Program Studi Akuntansi 4, no. 2 (2018): 51, https://doi.org/10.31289/jab.v4i2.1817; Trisilo, "Penerapan Akad Pada Obligasi Syariah Dan Sukuk Negara (Surat Berharga Syariah Negara/SBSN)," 22-23. 
sukuk is issued is as a counterweight to the wealth contained in the balance sheets of the government, monetary authorities, companies, banks and financial institutions, and other forms of entities that mobilize public funds. Issuers or parties that issue sukuk can come from government institutions, private companies, financial institutions, or monetary authorities. $^{14}$

\section{Definition of Sharia Bonds}

The word bond comes from the Dutch language, obligate or obligaat, which means obligations that cannot be abandoned or debt securities of a state or regional loan or company with a fixed interest. ${ }^{15}$ Bonds are one of the futures investment instruments in the conventional financial system. Bonds are debt securities that, based on regulations, investors get a fixed interest paid every month, and in the end, the

14 Ramadayanti, Mainata, and Pratiwi, "Peran Sukuk Negara Dalam Pembiayaan Infrastruktur," 159.

${ }^{15}$ Rina EL Maza, “Peluang Dan Tantangan Obligasi Syari'ah Dalam Penerbitannya," JEBI (Jurnal Ekonomi Dan Bisnis Islam 1, no. 1 (2016): 53, https://journal.febi.uinib.ac.id/index.php/jebi/article/v iew/4; Nurul Fatma Hasan and M. Mujib Utsmani, "Rekonstruksi Obligasi: Investasi Dalam Perspektif Syariah," Qawãnïn: Journal of Economic Syaria Law 1, no. 1 (January 14, 2017): 9, https://doi.org/10.30762/q.v1i1.483. issuer returns the principal amount of the debt to the investor after maturity. ${ }^{16}$

Bonds can also be interpreted as securities because these bonds have elements of securities, namely these securities have a practical value or equivalent to securities. ${ }^{17}$ Concerning bonds, Law Number 19 of 2008 concerning State Sharia Securities (SBSN) states: State Sharia Securities, hereinafter abbreviated as SBSN, or can be called State Sukuk, are state securities issued based on sharia principles, as evidence of the share of participation in SBSN assets, both in rupiah and foreign currencies. In the General Elucidation of Law Number 19 of 2008 concerning SBSN states: One form of Islamic financial instrument that has been issued by both corporations and the state is securities based on sharia principles, or internationally known as sukuk. ${ }^{18}$

So bonds that are conventionally traded in the capital market, according to

16 Rifa'i and Sina, "Analisis Perkembangan Dan Resistansi Sukuk Korporasi Dalam Produk Pasar Modal," 36.

17 Jubaidi Jubaidi, "Analisis Perbandingan Tingkat Permintaan Obligasi," Research Journal of Accounting and Business Management (RJABM) 4, no. 2 (2020): 185, https://doi.org/10.31293/rjabm.v4i2.4915.

18 Hanapi, "Penerapan Sukuk Dan Obligasi Syariah Di Indonesia," 147-48. 
Islamic economic terminology, have turned into "sharia bonds" and are termed "sukuk", although the 2003 DSN-MUI did not mention the word "sukuk" in the fatwa related to the capital market and sharia bonds. ${ }^{19}$ The investment income (yield) distributed by the issuer (mudharib) to sharia bondholders (shahib al-maal) must be free from non-halal elements and following the contract used. The contracts that can be used in sukuk (sharia bonds) based on the fatwa of the National Sharia Council (DSN-MUI), include: mudharabah, musyarakah, murabahah, salam, istihna and ijarah. ${ }^{20}$

The term sukuk is a new term introduced as a substitute for the term Islamic bonds. The meaning of sukuk in the modern Islamic perspective rests on the concept of monetized assets, called guarantees, which are received through issuing sukuk (taskeek). According to the DSN-MUI Fatwa No. 32/IX/-2002 concerning Sharia Bonds, in sharia bonds, the refund system is carried out in the form of profit-sharing, fees and margins.

${ }^{19}$ Hanapi, 148.

20 Fadllan Fadllan, "OBLIGASI SYARIAH; Antara Konsep Dan Implementasinya," IQTISHADIA: Jurnal
Although the DSN-MUI fatwa does not mention sharia bonds with the term sukuk, this fatwa is considered a fatwa on sukuk. ${ }^{21}$

\section{Difference between Sukuk and Bonds}

Sukuk is almost the same as conventional bonds, but what makes it different is the use of rewards and profitsharing instead of interest. The sukuk is accompanied by an underlying transaction in the form of certain assets that form the basis for the issuance of the sukuk, and the existence of a contract or guarantor between the parties, which is prepared based on sharia principles. With a concept like this, it is expected that funding through sukuk is carried out based on the value of the underlying asset issuance so that it will minimize the possibility of a funding facility exceeding the value of the asset. In addition, sukuk must also be structured Islamically so that

Ekonomi \& Perbankan Syariah 1, no. 2 (2015): 164, https://doi.org/10.19105/iqtishadia.v1i2.479.

${ }^{21}$ Hanapi, "Penerapan Sukuk Dan Obligasi Syariah Di Indonesia," 149. 
this financial instrument is safe and free from usury, gharar, and maisir. ${ }^{22}$

In contrast to conventional bonds, sukuk has several characteristics, namely: First, it is proof of ownership of a tangible asset or beneficial title; Second, income in the form of rewards (coupons), margins, and profit-sharing, according to the type of contract used; Third, free from elements of usury, gharar, and maisir; Fourth, publishing through a Special Purpose Vehicle (SPV); Fifth, require underlying assets; and, Sixth, the use of proceeds must be following sharia principles. ${ }^{23}$

In its development, sukuk became one of the best-known types of sharia securities and was most widely discussed by Islamic finance experts. Sukuk are not the same as bonds even though they are both fixed income securities because bonds are debt securities while sukuk are sharia securities based on asset securitization. ${ }^{24}$ In detail, the comparison of sukuk and bonds can be explained in table 1.

Table 1. Comparison of Sukuk and Bonds

\begin{tabular}{|r|c|c|c|}
\hline No. & Description & Sukuk & Bonds \\
\hline 1. & Publisher & Government, & Government, \\
corporation & corporation \\
\hline 2. & Instrument & Certificate of & Debt \\
& properties & $\begin{array}{r}\text { ownership/involvement } \\
\text { of an asset }\end{array}$ & $\begin{array}{c}\text { acknowledgement } \\
\text { instrument }\end{array}$ \\
\hline 3. & Income & Rewards, profit & Interest/coupon, \\
charing, margin & capital gain \\
\hline 4. & Period & Short-medium & Medium-long \\
\hline
\end{tabular}

22 Rifa'i and Sina, "Analisis Perkembangan Dan Resistansi Sukuk Korporasi Dalam Produk Pasar Modal," 37.

${ }^{23}$ Rifa'i and Sina, 37.
24 Ag Maulana and Husni Thamrin, "Analisis Literasi Sukuk Bagi Mahasiswa Fakultas Agama Islam Universitas Islam Riau," Jurnal Tabarru': Islamic Banking and Finance 4, no. 1 (December 18, 2020): 5, https://doi.org/10.25299/jtb.2021.vol4(1).6028. 


\begin{tabular}{|c|c|c|c|}
\hline 5. & $\begin{array}{l}\text { Underlying } \\
\text { asset }\end{array}$ & Required & Not required \\
\hline 6. & Stakeholders & $\begin{array}{l}\text { Obligors, SPV, } \\
\text { investors, trustees }\end{array}$ & $\begin{array}{l}\text { Obligor/issuer, } \\
\text { investor }\end{array}$ \\
\hline 7. & Price & Market Price & Market Price \\
\hline 8. & Investors & $\begin{array}{r}\text { Islamic, } \\
\text { conventional }\end{array}$ & Conventional \\
\hline 9. & $\begin{array}{l}\text { Principal } \\
\text { payment }\end{array}$ & $\begin{array}{r}\text { Bullet or } \\
\text { amortization }\end{array}$ & $\begin{array}{r}\text { Bullet or } \\
\text { amortization }\end{array}$ \\
\hline 10. & $\begin{array}{c}\text { Use of } \\
\text { published results }\end{array}$ & $\begin{array}{l}\text { Must comply with } \\
\text { sharia }\end{array}$ & Free \\
\hline
\end{tabular}

Source: Directorate of Sharia Financing Policy ${ }^{25}$

The main difference between sukuk and bonds is that sukuk must be applied with due regard to and following sharia principles to ensure that the sukuk is free from elements of usury and non-halal activities, which are forbidden in sharia principles. Every investment invested in sukuk must be free from non-halal activities and must comply with sharia principles. Several principles in shariacompliant financial transactions are emphasized on fair agreements, the use of a profit-sharing system, as well as prohibitions against usury, gharar, and maisir. ${ }^{26}$

\section{Issuance, Implementation, and \\ Development of Sukuk in Indonesia}

The factors that hinder the development of state sukuk in Indonesia are influenced by many elements. Some of these elements are the government, issuers, products, and investors. The government, in its role in developing state sukuk is still less aggressive, as can be seen from the lack of regulations issued by the government to develop Islamic financial

${ }^{25}$ Khatimah, "Sukuk Dan Kontribusinya Dalam Pembiayaan Pembangunan," 91.

${ }^{26}$ Purnamawati, “Perbandingan Sukuk Dan Obligasi (Telaah Dari Perspektif Keuangan Dan Akuntansi)," 66-67. 
instruments, especially state sukuk. ${ }^{27}$ State sukuk are Islamic financial instruments that are currently being discussed both domestically and internationally. The government developed this instrument as one of the strategies to create sources of state budget financing. ${ }^{28}$

The current regulations are perceived to be hampering the development of the domestic sukuk market, as contained in Bank Indonesia (PBI) regulation Number $5 / 12$ of 2004, which states that banks holding sukuk must hold them until maturity. This is considered to hamper the liquidity of the sukuk market. ${ }^{29}$ Meanwhile, in terms of issuers, the number of state sukuk issued is still minimal. In fact, with the issuance of state sukuk, it expands financing instruments that can help the country's development. Sukuk itself is an obstacle to its development because state sukuk are illiquid, meaning they cannot be traded at will but wait for the tenor to end. The secondary sukuk

\footnotetext{
${ }^{27}$ Nafsiah, "Analisis Pengembangan Sukuk Negara Dan Mekanisme Transaksinya Pada Pasar Modal Di Indonesia," 22.

28 Muhamad Kholid, "Implementasi Hukum Ekonomi Islam Dalam Surat Berharga Syariah Negara Indonesia," Jurnal Hukum Ekonomi Islam 3, no. 2 (2019):

113 ,
}

market is also still very underdeveloped. In addition, there are only two types of sukuk circulating in Indonesia, namely ijarah and mudharabah sukuk, so the innovation and development of more diverse sukuk structures are needed. ${ }^{30}$

Viewed from the investor's perspective, there is still much understanding in the community that investing in the capital market is haram and only investing funds in houses, land, gold even though the MUI has decreed through the DSNMUI that there are investment instruments in the Indonesian capital market based on economic principles Sharia, one of which is sukuk, which not only provides benefits to investors but also participates in the development of Indonesia in a better direction. ${ }^{31}$ Furthermore, the method of issuing sukuk can be done in several ways. Following international best practices, the issuance of sukuk can be done by several methods, namely:

https://www.jhei.appheisi.or.id/index.php/jhei/article /view/48.

${ }^{29}$ Nafsiah, "Analisis Pengembangan Sukuk Negara Dan Mekanisme Transaksinya Pada Pasar Modal Di Indonesia," 22.

${ }^{30}$ Nafsiah, 22.

${ }^{31}$ Nafsiah, 22.

Jurnal Ilmu Akuntansi dan Bisnis Syariah 
Table 2. State Sukuk Issuance Method

\begin{tabular}{|c|c|c|}
\hline $\begin{array}{c}\text { Book Building: } \\
\text { The selling agent } \\
\text { collects purchase } \\
\text { orders within a } \\
\text { predetermined bidding } \\
\text { period and is recorded } \\
\text { in the order book by } \\
\text { the book runner. }\end{array}$ & $\begin{array}{c}\text { Private Placement: } \\
\text { specified bidding } \\
\text { period. }\end{array}$ & $\begin{array}{c}\text { The issuer carries out } \\
\text { the issuance and sale of } \\
\text { securities to certain }\end{array}$ \\
& & conditions \\
\hline
\end{tabular}

Source: Ministry of Finance $2010^{32}$

If the sukuk is only issued domestically, then the three methods above are used. Meanwhile, if the issuance is carried out in the scope of the international market, it can only be done through the book building method. The mechanism is that the sale of sukuk is carried out through selling agents, where the selling agent collects purchase orders within an offering period. State sukuk series issued are coded: SNI using dollar (USD) denomination.

Since the issuance of the first sukuk in 2002 by PT. Indosat with an issuance value of Rp. 175 billion, which at that time was still using the term sharia bonds, its development was still relatively slow. After 13 years have passed, corporate sukuk issuance in the Indonesian capital market has only reached 80 sukuk issuances with a total value of $14,483.4$ billion. Of the 80 sukuk issuances, 41 are still outstanding with a nominal value of Rp. 8,284 billion, the remaining 39 sukuk have been repaid with a total value of $\mathrm{Rp}$. 6,039.4 billion.

The contract used for the entire issuance of corporate sukuk only uses two types of contracts, namely ijarah and mudharabah contracts. ${ }^{33}$ The opportunity

\footnotetext{
32 Khatimah, "Sukuk Dan Kontribusinya Dalam Pembiayaan Pembangunan," 89.

33 Eka Nuraini Rachmawati and Ab mumin Bin Ab ghani, "Akad Penerbitan Sukuk Di Pasar Modal Indonesia Dalam Perspektif Fikih," Al-'Adalah 14, no. 1 (2018): 252-53, https://doi.org/10.24042/adalah.v14i1.2203. 
for the development of corporate sukuk in Indonesia is tremendous, considering the population is predominantly Muslim. Based on Law No. 19 of 2008 concerning State Sharia Securities (SBSN), which makes Islamic bonds more popular, it is possible for corporations and the government to issue sukuk. ${ }^{34}$

The total issuance of sukuk with ijarah contracts was 53 emissions of sukuk, and the remaining 27 sukuk used mudharabah contracts until July 2015. Mudharabah sukuk were dominated by the financial sector, especially Islamic banking, while ijarah sukuk was issued by retail, manufacturing and infrastructure companies. The highest number of sukuk emissions used 53 emissions of ijarah contracts and 27 emissions of mudharabah contracts. The issuance of corporate sukuk in Indonesia only uses two contracts, namely the ijiarah contract and the mudharabah contract. In practice, it turns out that there are structural differences between ijarah contracts and other ijarah contracts, as well as mudharabah contracts, depending on the

\footnotetext{
34 Herli and Nuraniyah, "Reaksi Pasar Terhadap Penerbitan Obligasi Syariah (Sukuk) Di Indonesia," 2.

35 Rachmawati and Ab ghani, "Akad Penerbitan Sukuk Di Pasar Modal Indonesia Dalam Perspektif Fikih," 253.
}

conditions of each issuer (issuer), namely differences in underlying assets, the use of proceeds from the issuance of sukuk and the most likely contracts to be implemented, at the time of publication. Of the 48 sukuk issuances issued by 28 issuers, which use mudharabah contracts, seven structures and ijarah contracts use 12 structures (models). ${ }^{35}$

The development of sukuk in Indonesia can be seen from the participation of Bapepam and LK as regulators in the Indonesian capital market by issuing regulations on sharia bonds, namely regulation number IX.A.13 which regulates the contracts used in the issuance of sharia securities in the capital market. With the enactment of the state sukuk law, it can be estimated that the development of the sukuk market in Indonesia will be better than before. Moreover, investors' interest in the management and issuance of sukuk is quite significant, as shown by the current development of sukuk globally. ${ }^{36}$

Therefore, the sukuk product currently developing can be justified because

36 Munawiroh and Rumawi, "Melacak Investasi Syariah: Studi Perkembangan Sukuk Bagi Pasar Modal Syariah Di Indonesia," 1559. 
it is not selling money with money at different prices but selling tangible assets, represented by sukuk certificates. Likewise, the benefits of sukuk investment are not based on the level of benefits that lead to usury, but profits are obtained based on the profits of tangible assets, either in the form of rent, discounts, or profit sharing. It can be added that sukuk require that they carry out wealth transfers which are carried out through security activities, both in the form of transfers of financial bonds and property rights bonds. ${ }^{37}$

On the other hand, developing sukuk in Indonesia can be used as an investment instrument that provides opportunities for Muslim and non-Muslim investors to invest in Indonesia. So sukuk can be used to build the nation's economy and create community welfare. The facts so far show that the market is very responsive to the issuance of sukuk. Almost all of the sukuk issues were entirely absorbed by the market, even in some cases, it caused excess demand. The six sukuk that have been marketed are Indosat's Aneka Gas Industries' sukuk ijarah (Rp. 160 billion),

37 Ali Muhayatsyah, “Aspek Syariah Pada Instrumen Sukuk: Analisis Penerapan Sukuk Wakaf Di Indonesia," J-ISCAN: Journal of Islamic Accounting
Indosat III's sukuk ijarah (Rp. 570 billion), Metrodata Electronics' ijarah sukuk (Rp. 90 billion), and Summarecon Agung's ijarah sukuk (Rp. 200 billion). Bank Muamalah's ijarah sukuk (Rp 314 billion), Mayora Indah's ijarah sukuk (Rp. 200 billion).

Currently, the sukuk market share is not large, according to PT. Danareksa Sekuritas, the outstanding sukuk is only three per cent of the total sukuk market in Indonesia, conventional bonds still control the other 97 per cent. The existence of sukuk can strengthen Indonesia's economic conditions and hold back economic bubbles because it will increase the portfolio of foreign currencies other than the dollar. It is time for Indonesia to carry out its portfolio in dollars and other currencies. This will increase the foreign currency portfolio beyond the dollar. ${ }^{38}$

While the challenges of sukuk are considered prospective, they face many challenges. Some of the challenges include: First, insufficient socialization. It must be admitted that the Indonesian people are not yet familiar with the profitsharing system or other sharia systems.

Research 2, no. 2 (December 7, 2020): 86, https://doi.org/10.52490/j-iscan.v2i2.891.

${ }^{38}$ Maza, "Peluang Dan Tantangan Obligasi Syari'ah Dalam Penerbitannya," 62-63. 
The potential for Islamic bond investors from retail is quite enormous. Second, opportunity cost, which is translated as "second best choice". There is a direct or indirect comparison of the available options. Because the investor base of Islamic bonds is potentially extensive, like it or not, Islamic bonds based on profit sharing will face this. ${ }^{39}$

\section{CONCLUSION}

Sukuk are in principle the same as bonds, with the main differences, among others, in the use of the concept of return and profit-sharing as a substitute for interest, the existence of an underlying transaction in the form of a certain number of assets that form the basis for issuance, and the existence of a contract or agreement between the parties drawn up-based on sharia principles. The sukuk transaction is not a debt contract but an investment because debt securities give the impression that there is an interest that is not halal so it cannot be issued. This causes sukuk to be referred to as securities, not debt securities. In addition, sukuk must also be structured according to sharia so that these financial instruments are safe and free from usury, gharar and maisir. Sukuk can be an alternative investment for parties who consider the economic benefits and the halal aspect of the investment. 


\section{REFERENCES}

Atika, Atika, and Dwi Saraswati. "Analisis Pengaruh Penerbitan Dana Sukuk Terhadap Kinerja Perbankan Syariah." JURNAL AKUNTANSI DAN BISNIS : Jurnal Program Studi Akuntansi 4, no. 2 (2018): 49-61. https://doi.org/10.31289/jab.v4i2.1817.

Endri. “Permasalahan Pengembangan Sukuk Korporasi Di Indonesia Menggunakan Metode Analytical Network Process (ANP)." Jurnal Keuangan Dan Perbankan 13, no. 3 (2009): 359-72. http://jurnal.unmer.ac.id/index.php/jkdp/article/view/1085.

Fadllan, Fadllan. "OBLIGASI SYARIAH; Antara Konsep Dan Implementasinya." IQTISHADIA: Jurnal Ekonomi \& Perbankan Syariah 1, no. 2 (2015): 163-75. https://doi.org /10.19105/iqtishadia.v1i2.479.

Fasa, Muhammad Iqbal. “Sukuk: Teori Dan Implementasi.” Li Falah: Jurnal Studi Ekonomi Dan Bisnis Islam 1, no. 1 (2016): 80-94. https://doi.org/10.31332/lifalah.v1i1.476.

Hanapi, Hapil. "Penerapan Sukuk Dan Obligasi Syariah Di Indonesia." Jurnal Ilmu Akuntansi Dan Bisnis Syariah 1, no. 2 (2019): 145-62. https://journal.uinsgd.ac.id/index.php/ aksy/article/view/5553.

Hardianti, Nur Indah, and Agus Widarjono. "Dampak Penerbitan Sukuk Dan Obligasi Konvensional Terhadap Return Saham Perusahaan Di Indonesia." Jurnal Ekonomi $\mathcal{E}$ Keuangan Islam 3, no. 1 (2017): 43-51. https://doi.org/10.20885/jeki.vol3.iss1/art6.

Hasan, Nurul Fatma, and M. Mujib Utsmani. “Rekonstruksi Obligasi: Investasi Dalam Perspektif Syariah." Qawãnïn: Journal of Economic Syaria Law 1, no. 1 (January 14, 2017): 1-25. https://doi.org/10.30762/q.v1i1.483.

Herli, Mohammad, and Khalilatun Nuraniyah. "Reaksi Pasar Terhadap Penerbitan Obligasi Syariah (Sukuk) Di Indonesia" 6, no. 1 (2018): 1-30. http://prosiding.unipma.ac.id/ index.php/FIPA/article/view/436.

Hulwati, Hulwati. “Investasi Sukuk: Perspektif Ekonomi Syariah.” JEBI (Jurnal Ekonomi Dan Bisnis Islam) 2, no. 1 (2017): 85-96. https://doi.org/10.15548/jebi.v2i1.70.

Indriasari, Ika. “Sukuk Sebagai Alternatif Instrumen Investasi Dan Pendanaan.” BISNIS : Jurnal Bisnis Dan Manajemen Islam 2, no. 1 (2014): 61-76. https://doi.org/10.21043/ bisnis.v2i1.5250.

Jubaidi, Jubaidi. “Analisis Perbandingan Tingkat Permintaan Obligasi.” Research Journal of Accounting and Business Management (RJABM) 4, no. 2 (2020): 183-95. https: //doi.org/10.31293/rjabm.v4i2.4915. 
Khatimah, Husnul. "Sukuk Dan Kontribusinya Dalam Pembiayaan Pembangunan." Optimal: Jurnal Ekonomi Dan Kewirausahaan 11, no. 1 (2017): 83-103. https://doi.org/10.33558/ optimal.v11i1.211.

Kholid, Muhamad. "Implementasi Hukum Ekonomi Islam Dalam Surat Berharga Syariah Negara Indonesia." Jurnal Hukum Ekonomi Islam 3, no. 2 (2019): 113-32. https://www.jhei. appheisi.or.id/index.php/jhei/article/view/48.

Latifah, SIti. "Peran Sukuk Surat Berharga Syariah Negara (SBSN) Dalam Pertumbuhan Pembangunan Ekonomi Indonesia." Jurnal Ilmiah Ekonomi Islam 6, no. 3 (2020): 421-27. https://doi.org/10.29040/jiei.v6i3.1369.

Maulana, Ag, and Husni Thamrin. "Analisis Literasi Sukuk Bagi Mahasiswa Fakultas Agama Islam Universitas Islam Riau." Jurnal Tabarru': Islamic Banking and Finance 4, no. 1 (December 18, 2020): 1-12. https://doi.org/10.25299/jtb.2021.vol4(1).6028.

Maza, Rina EL. "Peluang Dan Tantangan Obligasi Syari'ah Dalam Penerbitannya." JEBI (Jurnal Ekonomi Dan Bisnis Islam 1, no. 1 (2016): 53-65. https://journal.febi.uinib.ac.id/ index.php/jebi/article/view/4.

Muhayatsyah, Ali. “Aspek Syariah Pada Instrumen Sukuk: Analisis Penerapan Sukuk Wakaf Di Indonesia." J-ISCAN: Journal of Islamic Accounting Research 2, no. 2 (December 7, 2020): 67-91. https://doi.org/10.52490/j-iscan.v2i2.891.

Munawiroh, Afifatul, and Rumawi. "Melacak Investasi Syariah: Studi Perkembangan Sukuk Bagi Pasar Modal Syariah Di Indonesia." Kertha Semaya 8, no. 10 (2020): 1551-65. https://doi.org/10.24843/KS.2020.v08.i10.p06.

Nafsiah. "Analisis Pengembangan Sukuk Negara Dan Mekanisme Transaksinya Pada Pasar Modal Di Indonesia." Al-Infaq, Ekonomi Islam 5, no. 1 (2014): 15-26. http://ejournal.uika-bogor.ac.id/index.php/al-infaq/article/view/40.

Nasrifah, Maula. "Sukuk (Obligasi Syariah) Dalam Perspektif Keuangan Islam." AsySyari'ah: Jurnal Hukum Islam 5, no. 2 (June 15, 2019): 165-79. https://doi.org/10.36835/ assyariah.v5i2.120.

Purnamawati, Indah. "Perbandingan Sukuk Dan Obligasi (Telaah Dari Perspektif Keuangan Dan Akuntansi)." Jurnal Akuntansi Universitas Jember 11, no. 1 (2015): 62-71. https://doi.org/ 10.19184/jauj.v11i1.1261.

Rachmawati, Eka Nuraini, and Ab mumin Bin Ab ghani. "Akad Penerbitan Sukuk Di Pasar Modal Indonesia Dalam Perspektif Fikih." Al-'Adalah 14, no. 1 (2018): 22562. https://doi.org/10.24042/adalah.v14i1.2203. 
Ramadayanti, Rizky Suci, Dedy Mainata, and Angrum Pratiwi. "Peran Sukuk Negara Dalam Pembiayaan Infrastruktur." Al-Tijary 2, no. 2 (January 2, 2017): 155-76. https://doi.org/ 10.21093/at.v2i2.788.

Rifa'i, M Anwar, and Rois Ibnu Sina. “Analisis Perkembangan Dan Resistansi Sukuk Korporasi Dalam Produk Pasar Modal." Jurnal Ekonomi Dan Perbankan Syari'ah 11, no. 1 (2019): 33-46. https://doi.org/10.24235/amwal.v11i1.4406.

Trisilo, Rudi Bambang. "Penerapan Akad Pada Obligasi Syariah Dan Sukuk Negara (Surat Berharga Syariah Negara/SBSN)." Economic: Jurnal Ekonomi Dan Hukum Islam $4, \quad$ no. $\quad 1 \quad$ (2014): http://ejournal.kopertais4.or.id/tapalkuda/index.php/economic/ article/view/782. 